\title{
Strukturasi proses produksi film horor Pengabdi Setan: Perspektif ekonomi politik
}

\author{
Umaimah Wahid ${ }^{1}$, Shena Agustina ${ }^{2}$ \\ ${ }^{1,2}$ Universitas Budi Luhur, Jakarta, Indonesia
}

\begin{abstract}
ABSTRAK
Film tidak hanya berfungsi sebagai media hiburan. Film juga berperan dalam menyampaikan pesan-pesan ideologi yang secara sadar atau tidak sadar menjadi bagian nilai yang diyakini oleh penonton. Di samping itu, alasan produksi film horor meningkat karena nilai ekonomi dan politik yang menjadi bagian dari struktur dan agen-agen sosial. Salah satu film horor fenomenal pada tahun 2017 adalah film Pengabdi Setan karya Joko Anwar yang meraih jumlah penonton 4,2 juta orang. Penelitian menggunakan teori strukturasi Anthony Gidden dan perspektif ekonomi politik Vincent Mosco. Objek penelitian adalah struktur sosial dan agen dalam proses pembuatan film. Subjek penelitian adalah para pihak yang terlibat dalam proses pembuatan film. Pendekatan kualitatif dengan metode studi kasus digunakan dalam penelitian ini. Data dihasilkan melalui teknik pengumpulan data wawancara dan observasi. Hasil penelitian menjelaskan bahwa proses produksi film terdiri dari pra produksi, produksi dan pasca produksi. Semua proses melibatkan agenagen sosial yang terikat dengan struktur sosial dan produksi film sangat tergantung pada nilai ideologi dan ekonomi politik. Nilai ekonomi menjadi tujuan utama film Pengabdi Setan diproduksi ulang dengan berbagai prubahan menyesuaikan struktur sosial penonton saat ini. Proses produksi terkooptasi oleh niai-nilai yang mengikat struktur perfilman Indonesia, khususnya dalam pembuatan film. Film Pengabdi Setan telah mampu menciptakan ketidaksadaran masyarakat terhadap realitas isi film sebagai representasi langsung masyarakat yang terikat oleh struktur dimana film diproduksi.
\end{abstract}

Kata-kata Kunci: Produksi; strukturasi; ekonomi politik; media; film horor

\section{The Structure of the Production Process of Satanic Servant Horror Films; Political Economy Perspective}

\begin{abstract}
Audiences engage in films as entertainment media; however, the film also conveys ideology. The production of horror films increases because of the economic and political purposes that are part of the structure and social agents. One of the phenomenal horror films in 2017 is the film Pengabdi Setan (Satan's Slave) by Joko Anwar. The research used the structuration theory of Anthony Gidden and Vincent Mosco's politicaleconomic perspective. The object of research was the social structure and agents in the process of filmmaking. The research conducted a qualitative approach with the case study method. The data is generated through data collection techniques, interviews and observations. The study results explained that the film production process consists of pre-production, production, and postproduction. All procedures involving social agents interested in social structure and film production are highly dependent on ideological values and political economy. Economic value is the primary purpose of the film. The film Pengabdi Setan is reproduced with various changes to adjust the audience's social structure today. The production process is co-opted by the values that adhere to the Indonesian film structure, especially in the film. Pengabdi Setan film has been able to create a public unconscious of the relativity of the contents of the film as a direct representation of society bound by the structure in which the film is produced.
\end{abstract}

Keywords: Production; structuration; political economy; media; horror movies

Korespondensi: Dr. Umaimah Wahid, M.Si. Universitas Budi Luhur. Jl. Ciledug Raya, Kota Jakarta Selatan 12260.Email: umaimah.wahid@budiluhur.ac.id 


\section{PENDAHULUAN}

Produksi film Indonesia dalam beberapa tahun terakhir kembali tumbuh dan meningkat dari segi kuantitas dan kualitas. Pertumbuhan film ditandai dengan geliat industri film tanah air yang tidak sepi memproduksi berbagai genre film dan didukung oleh jumlah penonton film yang semakin banyak. Jumlah produksi film Indonesia meningkat walau ditengah lesunya perfilman tanah air (Wijiharjono, 2017). Tahun 2018, pengeluaran uang untuk menonton film mencapat 1.6 Triliun dari jumlah penonton 42.854.460 orang, sedangkan tahun 2019 mencapai 1,8 Trilyun dengan jumlah penonton 45.318.972. Angka-angka tersebut bermakna bahwa masyarakat semakin menyukai menonton film Indonesia sebagai media hiburan, sekaligus media yang mengandung pesan ekonomi. Merujuk pada Handayani, film merupakan salah satu sumber informasi yang berfungsi sebagai sarana penghibur, sekaligus sebagai media komunikasi massa yang membawa pesan dan gambar pada khalayak, mempunyai potensi ekonomi (Permana et al., 2018). Film tidak hanya mempunyai potensi ekonomi yang besar tetapi juga merupakan representasi dari nilai sosial dan budaya. Industri film merupakan salah satu sektor ekonomi budaya, dibagi menjadi cabang-cabang utama seperti bioskop, TV, film dan seri iklan (Incekara et al., 2013).
Film diproduksi dalam berbagai genre. Salah satu genre yang menarik penonton adalah film bergenre horror. Genre film adalah berdasarkan jenis dan alur cerita (Javandalasta, 2011). Beberapa genre film diantaranya adalah horror, film aksi, drama, epik sejarah, fantasi, komedi, kriminal, gangster, musikal, dan petualangan (Oktavianus, 2015). Selain itu, film hiburan juga merupakan genre yang paling diminati oleh penonton.

Pada tahun 2017, film Pengabdi Setan diproduksi ulang oleh Joko Anwar. Film ini diproduksi oleh dua rumah produksi yaitu Rapi Films dan CJ Entertainment. Diperankan oleh Tara Basro, Dimas Aditya, Bront Palarae, Ayu Laksmi, Endy Arfian, Fachri Albar, Asmara Abigail, dan lainnya. Film Pengabdi Setan telah ditonton oleh 4.206.103 dan merupakan satusatunya film horor Indonesia terlaris sepanjang masa (Databoks.com, 2017). Film ini juga ditayangkan di 42 negara (Khoiri, 2018). Selain itu, film Pengabdi Setan memperoleh tujuh (7) Piala Citra pada ajang Festival Film Indonesia 2017, memenangkan Kategori Film Terseram dalam Festival Film Horor Popcorn Frights, yang diselenggarakan di Florida, Amerika Serikat (Vivanews.com, 2018), dan beberapa penghargaan lainnya.

Proses pembuatan film Pengabdi Setan adalah salah satu proses perjuangan sungguhsungguh sutradara Joko Anwar dalam penentuan 
lokasi syuting dan setting yang dianggap dapat mewakili visualisasi cerita. Tim produksi membutuhkan waktu selama empat bulan untuk pencarian lokasi hingga akhirnya daerah Pengalengan menjadi pilihan. Tim produksi mendesain ulang rumah tersebut seperti nuansa film Pengabdi Setan tahun 80-an walau dari segi cerita, penamaan tokoh dan alur berbeda. Film Pengabdi Setan 2017 melakukan rekonstruksi sesuai dengan struktur sosial dan agensi abad 21 dan upaya tersebut mendulang kesuksesan (Vivanews.com, 2018).

Anthony Gidden berpendapat bahwa film bukan hanya sebagai media hiburan, melainkan sebagai media yang mengkonstruksi pesan dan dalam proses produksinya tidak terlepas dari keterlibatan 'dualisme' utama yaitu struktur sosial dan agen-agen (Giddens, 2011). Film juga merupakan sarana ampuh untuk mendoktrinasi ideologi-ideologi tertentu secara terang-terangan maupun terselubung kepada masyarakat. Kekuatan dampak dari sebuah film sebagai media yang memiliki andil membentuk budaya dan cara pandang masyarakat mengenai sebuah nilai dan budaya. Budaya dalam masyarakat seringkali dibentuk oleh film yang mencerminkan nilai-nilai dan ideologi (Nugraeni, 2014).

Adapun rumusan masalah penelitian adalah bagaimana strukturasi dan ekonomi politik media berlangsung dalam proses produksi film
Pengabdi Setan karya sutradara Joko Anwar? Sedangkan tujuan penelitian ini adalah untuk mengungkapkan adanya kekuatan strukturasi dan ekonomi politik dalam proses pembuatan film Pengabdi Setan.

\section{METODE PENELITIAN}

Penelitian mengenai strukrasi proses produksi film ini menggunakan pendekatan kualitatif dan metode studi kasus (case study). Studi kasus adalah penelitian yang dilakukan sebagai upaya menjawab pertanyaan masalah penelitian yang menfokuskan pada How dan Why (Creswell, 2013). Objek penelitian adalah strukturasi dan ekonomi politik dalam perfilman horror Indonesia dalam proses pembuatan film horror Pengabdi Setan 2017 dilihat dari sudut pandang ekonomi politik media sedangan subyek penelitian ini terdiri dari key informant dan informan. Key informan adalah mereka yang dapat memberikan keterangan tentang informasi/data dan sekaligus memungkinkan memberikan saran kepada peneliti tentang sumber-sumber bukti pendukung lainnya serta menciptakan akses terhadap sumber-sumber bukti lain yang mendukung lainnya (Yin, 2013). Dalam penelitian ini, key informan dan informan adalah narasumber yang terlibat dalam pembuatan film Pengabdi Setan yaitu Melisa Hana Kristiant sebagai Casting Director. Ismawati sebagai Marketing dan Publisis Rapi 
Films yaitu Yusuf Rizal Sulaeman sebagai Publisis Eksternal, Egy Fedly (aktor dan seniman).

Dalam upaya melengkapi daya, peneliti juga memilih 3 orang informan yang merupakan penonton atau dengan kata lain adalah orangorang yang sudah menonton film Pengabdi Setan 2017. Ketiga informan tersebut dipilih secara random guna memperkuat kelengkapan data mengenai strukturasi dan konstruksi dalam pembuatan film Pengabdi Setan 2017. Objek penelitian merupakan sasaran untuk mendapatkan suatu data. Film Pengabdi Setan merupakan film horror Indonesia terlaris pada tahun 2017 versi reboot nya di sutradarai oleh Joko Anwar. Penelitian dilakukan sejak November 2017 sampai dengan Juli 2018 di kantor Production House Rapi Films, J1. Cikini 2 No 7 A Cikini, Menteng, Jakarta Pusat, Daerah Khusus Ibukota Jakarta 10330. Dalam upaya menjaga keabsahan data, peneliti menggunakan Triangulasi Sumber dengan tujuan mengangalisis data secara komprehensif. Dilakukan pengecekan data dari sumber-sumber wawancara, observasi dan dokumen yang relevan dengan harapan dapat memperoleh kebenaran dan analisis yang tepat dan tajam sebagai upaya pemaknaan terhadap data.

\section{HASIL DAN PEMBAHASAN}

Produksi film tidak mungkin lepas dari struktur sosial di mana agen-agen atau dalam konteks ini adalah para pihak yang terlibat dalam melahirkan tindakan mereka sesuai dengan ideologi dan sistem yang mereka yakini. Film mempunyai kekuatan dalam menyampaikan secara luas kepada masyarakat yang kemudian konstruksi pesan yang dikemas mempersuasi penonton. Film merupakan media yang sangat efektif untuk menyampaikan pesan atau sebagai sarana komunikasi antara lain adalah film karena film memiliki banyak penonton atau penikmat di seluruh dunia (Sutorini et al., 2019). Pesan yang disampaikan dalam film berbentuk kisah atau cerita, dimana menjadi sarana bagi suatu lembaga untuk menyebarluaskan suatu pesan atau informasi (Sutorini et al., 2019). Ketergantungan penonton terhadap makna isi film menciptakan tindakan dalam struktur sosial yang melahirkan tindakan-tindakan sebagai agen sosial serta membentuk budaya.

Merujuk pada Undang-Undang Nomor 33 Tahun 2009 tentang perfilman pada Bab I Pasal 1 menyebutkan, film adalah karya seni budaya yang merupakan prananta sosial dan media komunikasi massa yang dibuat berdasarkan kaidah sinematografi dengan atau tanpa suara dan dapat dipertunjukan (Vera, 2014). Produksi sebuah film tidak mungkin dilepaskan dari nilai sosial budaya berupa pranata sosial, termasuk struktur dan agenagennya. Proses strukturasi terus berlangsung 
dalam interaksi sosial, komunikasi dan ekonomi untuk mendukung produksi, termasuk produksi film horror. Karakteristik budaya film horor Indonesia cenderung melekat dengan kehidupan supranatural, sedangkan film horror Eropa dan Amerika cenderung lebih rasional. Film horror memiliki dua ciri khas utama: penampilan sosok yang jahat atau mengerikan (termasuk psikopat yang suka membunuh) dan elistasi ketakutan atau perasaan jijik bagi penonton. Keberhasilan sebuah film ditentukan oleh proses pra-produksi, produksi dan pascaproduksi (Nickel, 2010).

Dalam pembuatan film Pengabdi Setan, kegiatan produksi dan produk audio visual lainnya secara umum terdiri atas tiga proses yaitu kegiatan pra produksi, produksi, dan post produksi. Joseff Steiff menyebutkan setiap tahap pembuatan film didefinisikan sebagai berikut: 1) Pra-produksi yaitu fase persiapan perencanan film dibuat, termasuk rekruitmen kru pemain dan kru film, memilih lokasi, set bangunan, mengedit/menyelesaikan skrip, dan menghasilkan tujuan jauh selanjutnya, 2) Produksi, yaitu fase di mana elemen mentah direkam dan difilmkan selama pemotretan dan 3) Pasca produksi yaitu fase di mana pencitraan, pengeditan/pencampuran suara, dan efek visual ditambahkan, diselesaikan dan dikoreksi untuk menyajikan film akhir (Cheng, 2014).

Pertama proses Pra-produksi film Pengabdi
Setan 2017 dimulai dengan proses seleksi (casting) yang dilakukan selama kurang lebih satu bulan yang melibatkan sutradara, produser, dan casting director. Kemudian dilakukan pencarian lokasi yang sesuai plot naskah dan umumnya ada beberapa pemeran yang ikut serta untuk melakukan latihan acting di lokasi shooting yang bersangkutan. Tahap pencarian lokasi ini juga berdasarkan latar belakang yang sesuai dengan set dari dialog atau naskah, dan efek psikologis yang diharapkan sampai kepada penonton. Alur proses tahap pra-produksi sebagaimana dalam gambar 1 .

Kedua, proses produksi adalah aktivitas pengambilan gambar adegan (take shot) atau shooting sesuai dengan jadwal shooting yang telah dibuat. Jadwal shooting secara garis besar tercantum pada breakdown dan detail jadwal setiap harinya berupa rundown kegiatan Produksi sebuah film sifatnya kolaboratif yaitu kerja yang menuntut keterlibatan sungguhsungguh semua pihak yang terlibat dalam proses produksi. Alur proses kerja tahap produksi sebagaimana dalam gambar 2 .

Produksi sebuah film sifatnya kolaboratif yang melibatkan sejumlah orang dengan keahlian yang berbeda-beda. Proses pencarian lokasi shooting seperti yang dijelaskan pada paragraf sebelumnya sekitar empat bulan, karena penentuan lokasi juga mesti yang sesuai dengan latar atau cerita pada film yang 


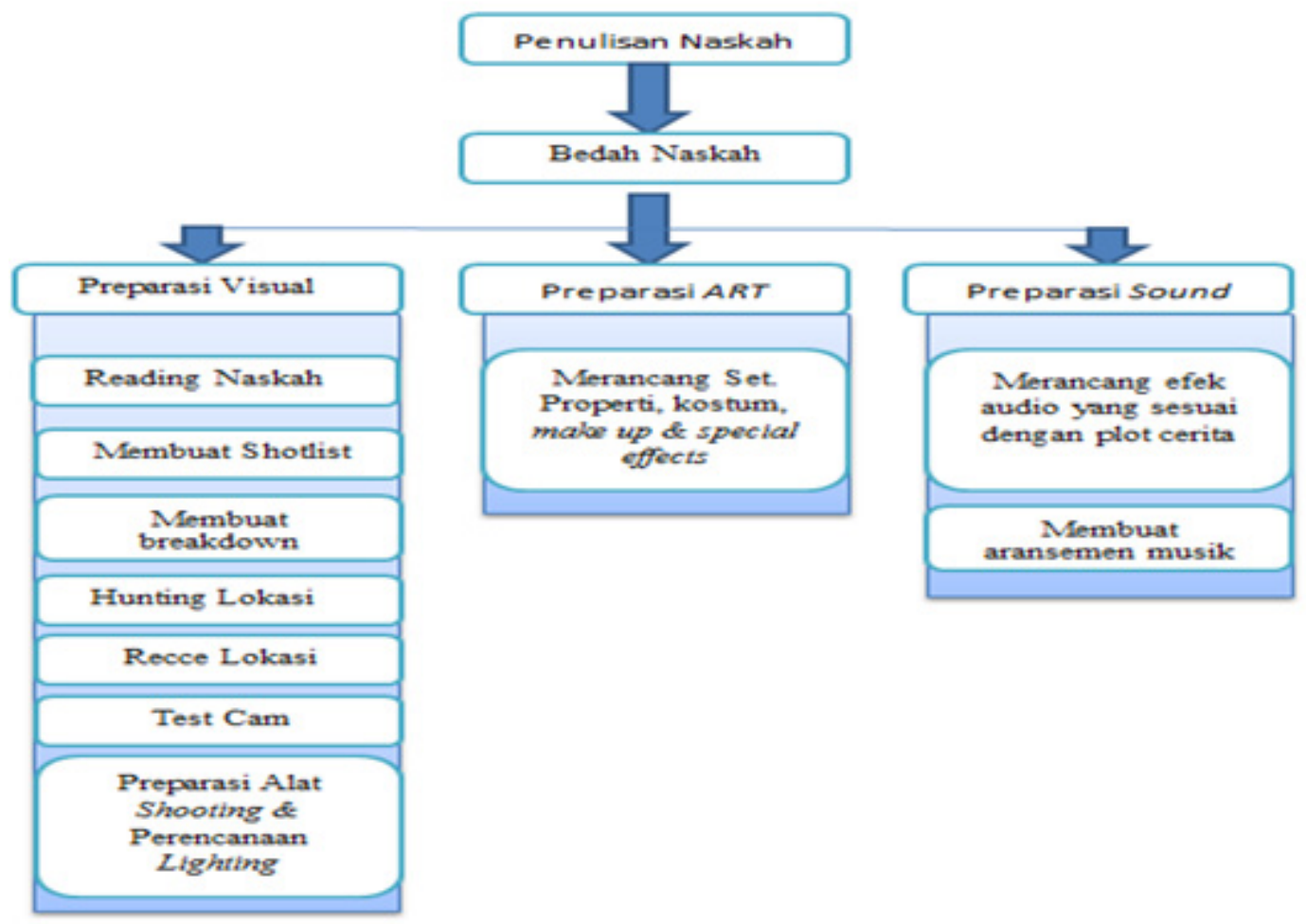

Sumber: Hasil Wawancara dengan Casting Director, 2018

\section{Gambar 1 Alur Kegiatan Pra Produksi}

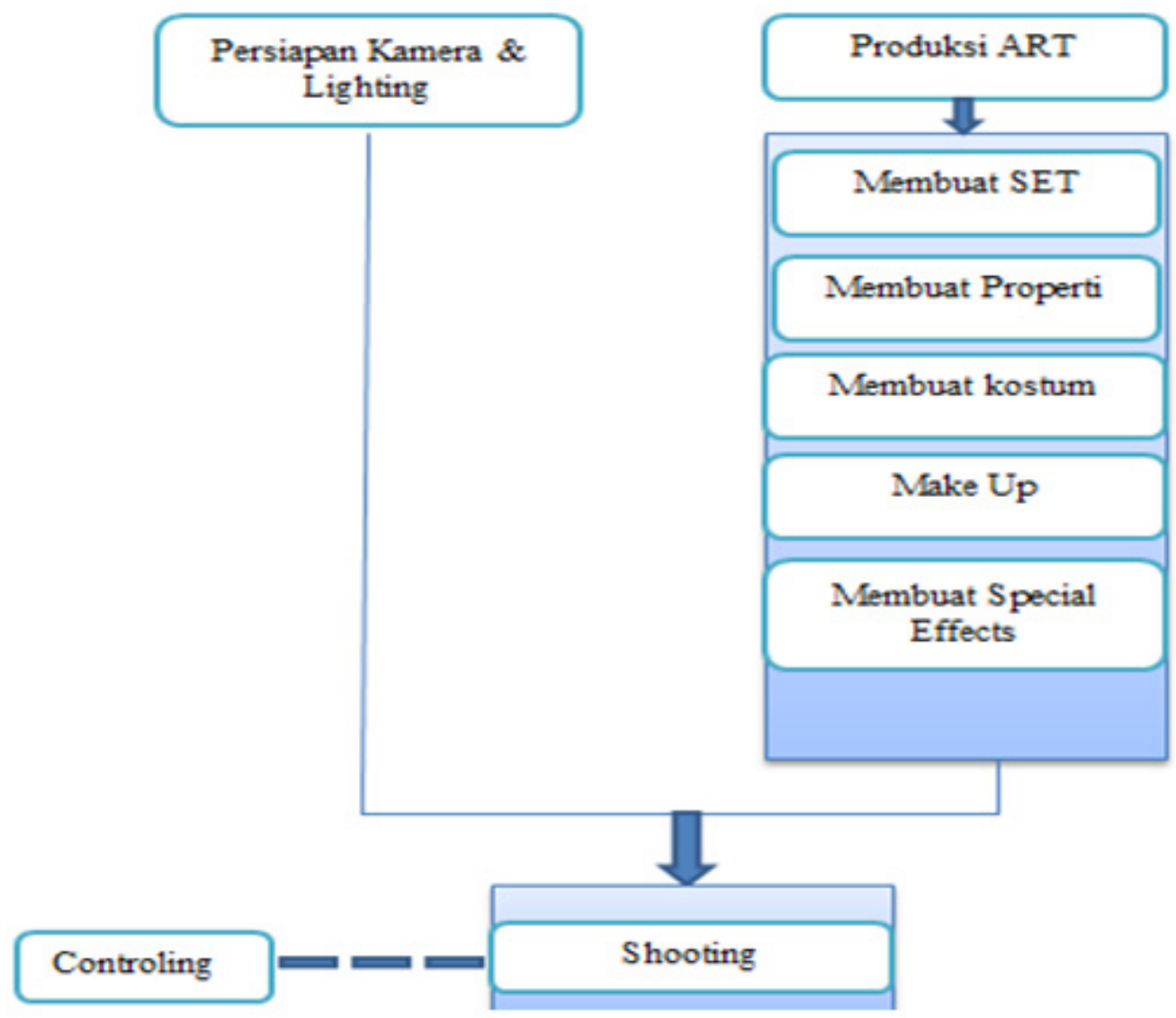

Sumber: Hasil Wawancara Dengan Casting Director, 2018

Gambar 2 Alur Kegiatan Produksi 
sebelumnya telah dilakukan diskusi dari sutradara dan kru lainnya. Dilakukan shooting di lokasi Pengalengan Jawa Barat itu sendiri selama 2 minggu.

Ketiga, post produksi, yaitu hasil perekaman gambar diolah dan digabungkan dengan hasil rekaman suara. Aspek terpenting dalam kegiatan post produksi adalah: 1) Editing offline yaitu tahapan penyuntingan kasar, dimana setiap adegan sudah disusun sesuai dengan urutan pada naskah. Pada proses editing offline ini, hanya dilakukan penyuntingan adegan per adegan, tanpa memasukkan efek suara dan efek audio lain seperti musik latar (music scoring). Tahap editing offline selesai ketika susunan adegan dalam film telah sesuai dengan plot cerita dan sudah disetujui oleh sutradara dan pihak produser yang disebut pictured locked. Sedangkan 2) Editing online yaitu kegiatan yang dilakukan setelah melalui tahap pictured locked. Susunan adegan mencapai tahap pictured locked, kemudian ditambahkan efek suara, music scoring dan efek visual lain seperti coloring, animation, serta special effect. Adapun langkah terakhir adalah melakukan proses mixing, dimana hasil suntingan audio dan suntingan akhir. Alur proses tahap pasca produksi sebagaimana dalam gambar 3 .

Produksi sebuah film sebagaimana produk media lainnya selalu terkait dengan kepentingan ekonomi politik media. Media film sebagai industri juga terikat dengan kepentingan ekonomi bahkan politik. Salah satu unsur yang dominan dalam pembuatan sebuah film adalah komodifikasi (commodification) yang berorientasi pada kepentingan kapital.

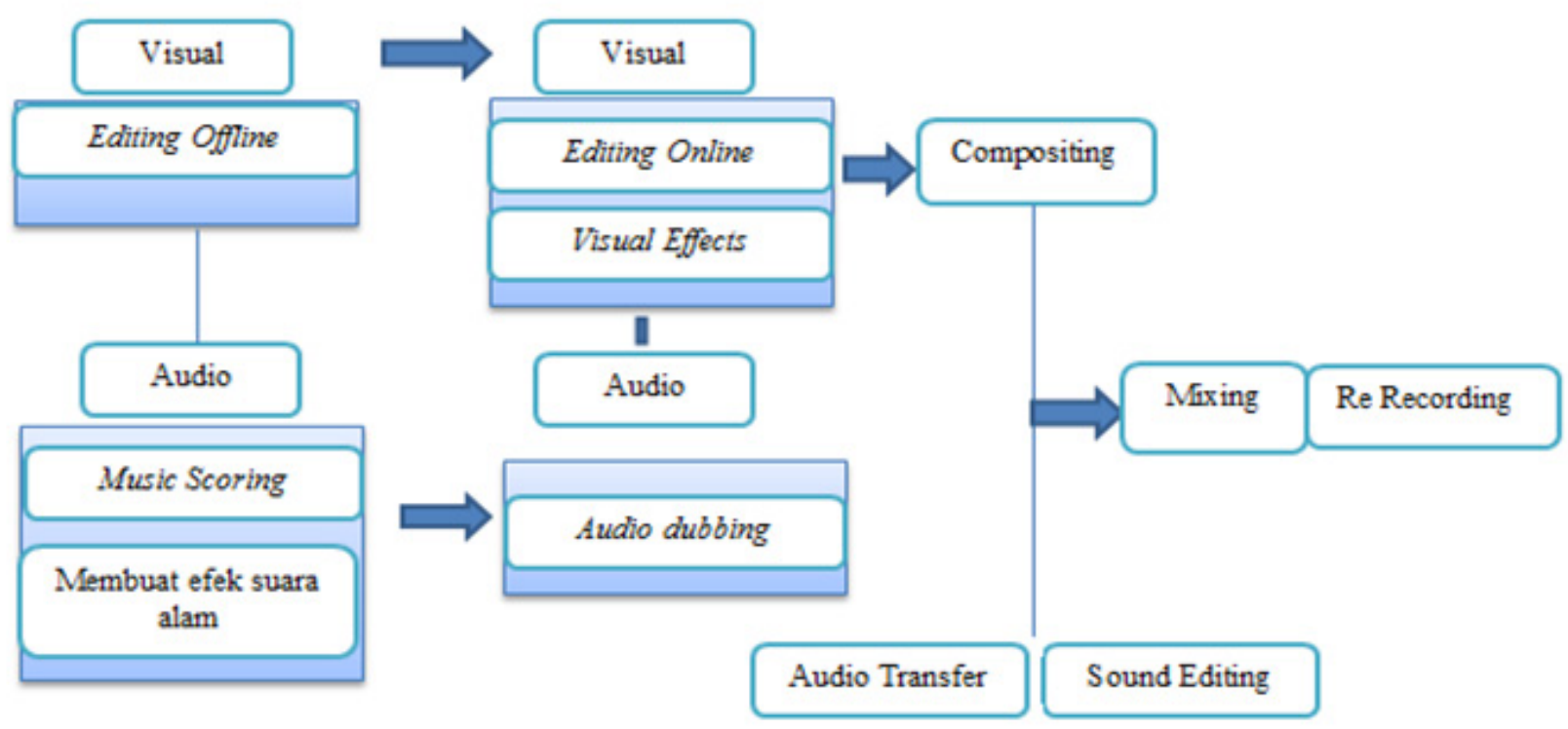

Sumber: Hasil Wawancara Dengan Casting Director, 2018

Gambar 3 Alur Kegiatan Post Produksi 
Media dalam proses produksi, distribusi dan konsumsi menurut perspektif ekonomi politik tidak mungkin dilepaskan dari kepentingan baik kepentingan pemilik modal, negara atau kelompok lainnya (Dwita, 2016). Film mampu menghasilkan pendapatan besar dalam industri hiburan, sekaligus representasi sosial budaya yang mengandung nilai ekonomi tinggi (Permana et al., 2018). Produk film merepresentasikan nilai ekonomi, politik dan ideologi kebudayaan. Penyesuaian dan perubahan yang dilakukan merupakan bentuk komodifikasi film, yang juga didukung oleh strukturasi saat ini. Demikian juga film Pengabdi Setan, semua agen melekatkan nilai-nilai dalam proses pembuatan film secara sadar. Kesadaran tersebut melekat dalam tataran praktis produser, sutradara dan para pihak yang terlibat dalam proses produksi film Pengabdi Setan.

Pemaknaan menurut konsep strukturasi Giddens dapat dilihat dalam film Pengabdi Setan dengan membandingkan film Pengabdi Setan 1980 dan Pengabdi Setan 2017 penulis gambarkan di dalam tabel 1.

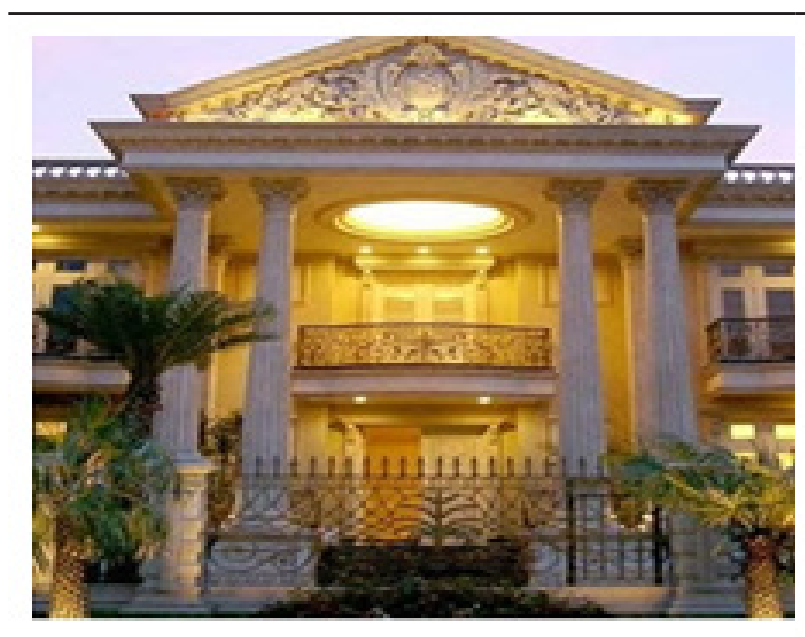

Dilatarbelakangi oleh keluarga yang kaya raya alur cerita di Pengabdi Setan 1980 ke menekankan pada hal hal mengenai agama. Film masa-masa orde baru lebih sering menilik hal-hal yang berbau SARA.

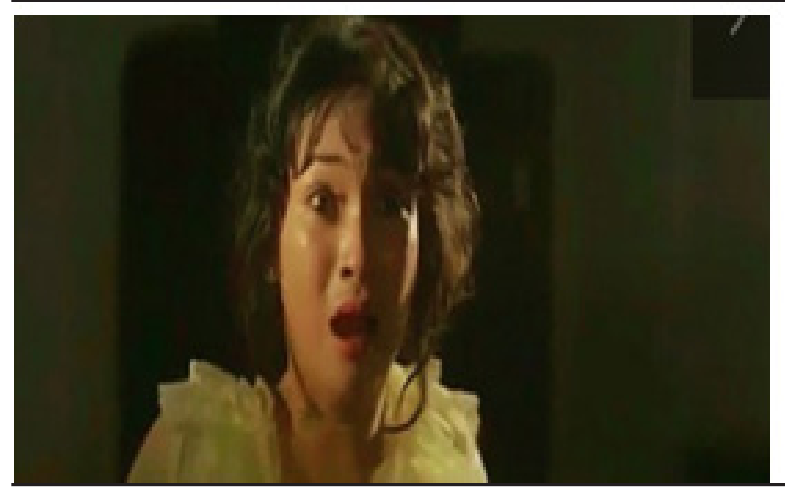

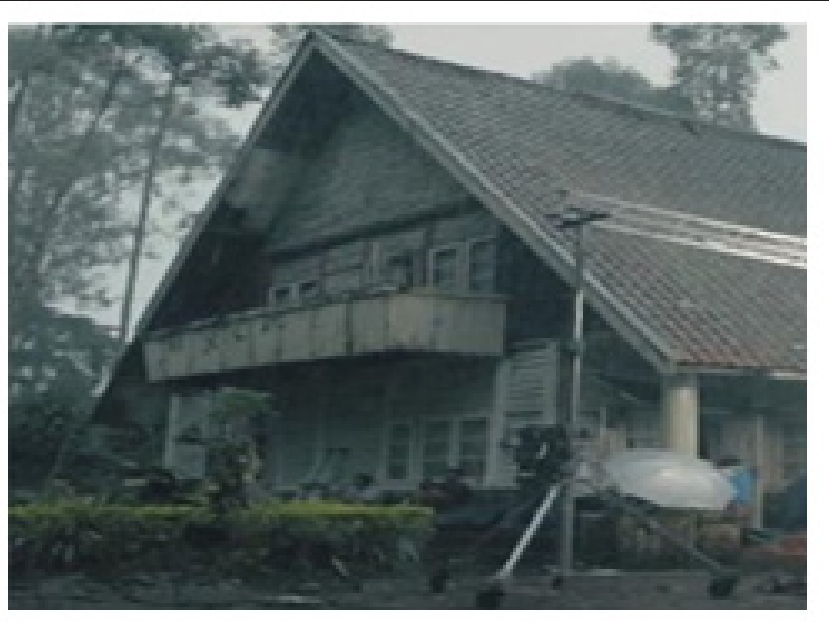

Untuk Pengabdi Setan 2017 justru berasal dari keluarga miskin dengan menggadaikan rumah untuk pengobatan ibu. Tidak banyak unsur agama hanya satu karakter yang menjadi anak seorang ustaz. Namun persamaannya film tersebut menceritakan keluarga yang jauh dari Tuhan.

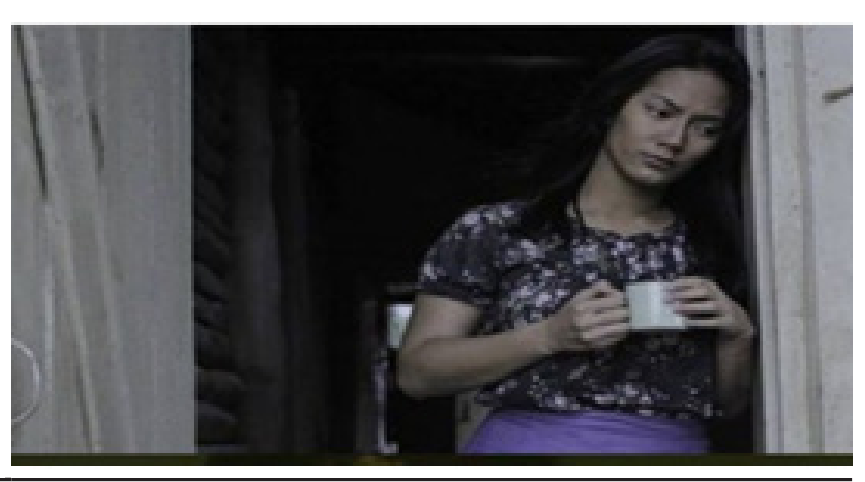


Di film Pengabdi Setan 1980 pemeran utamanya bernama Rita yang dinarasikan sebagai anak muda gaul pada masanya yang sering pergi clubbing dan pulang malam.
Sedangkan di Pengabdi Setan 2017 pemeran utama bernama Rini, seorang gadis yang terpaksa putus kuliah karena terhalang biaya dan menjadi pengganti ibu untuk mengurus kebutuhan adikadiknya.

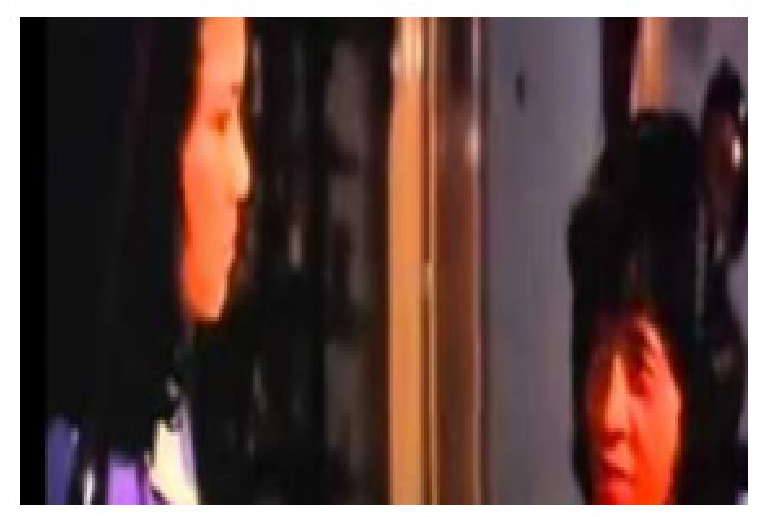

Dalam film Pengabdi Setan 1980, Rita memiliki kekasih bernama Herman. Sama halnya dengan Rita, Herman pun memiliki hobi yang sama.

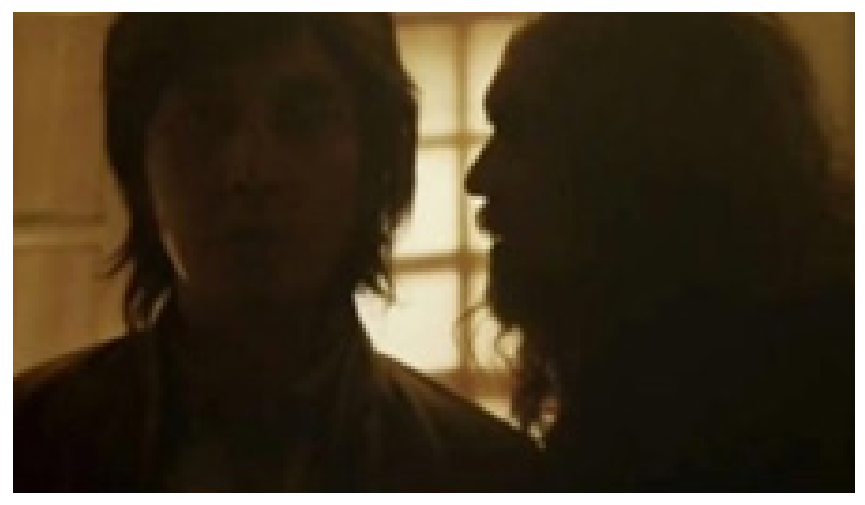

Sedangkan di film Pengabdi Setan 2017, Rini didekati oleh anak pak Ustaz bernama Hendra. Selain lemah lembut, ia juga rajin beribadah dan sayang keluarga.

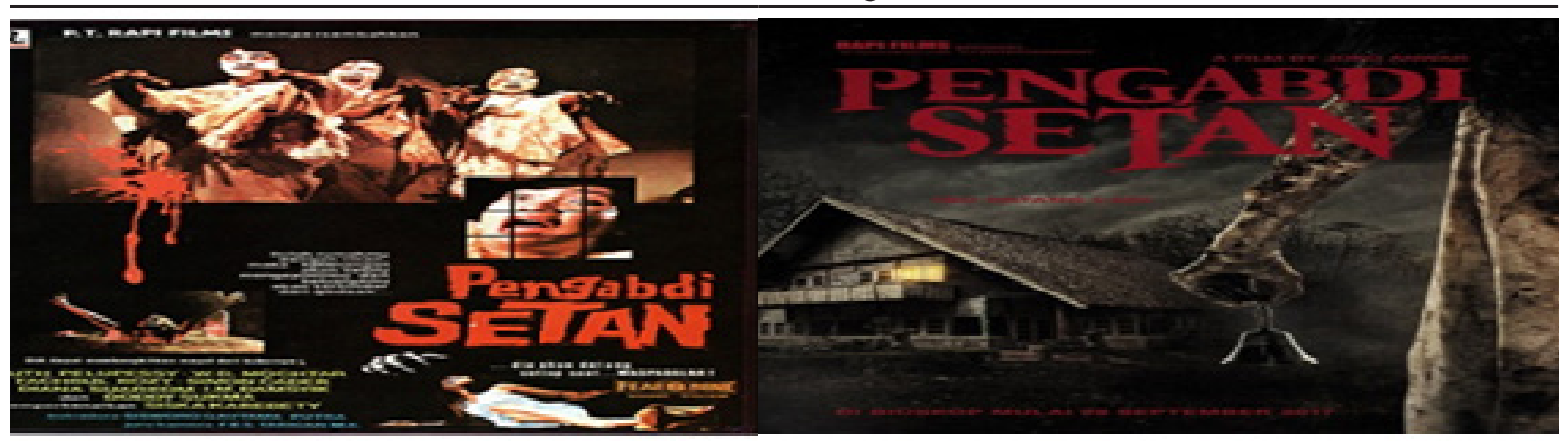

Pada poster Pengabdi Setan 1980 hantuhantu terlihat jelas dan memberikan kesan yang begitu mengerikan
Sedangkan di Pengabdi Setan 2017 memiliki 4 orang anak yaitu Rini, Tony, Bondy, dan Ian. Hubungan mereka akur namun yang mengejutkan bahwa Ian adalah anak dari Pengabdi Setan dan harus ditumbalkan.

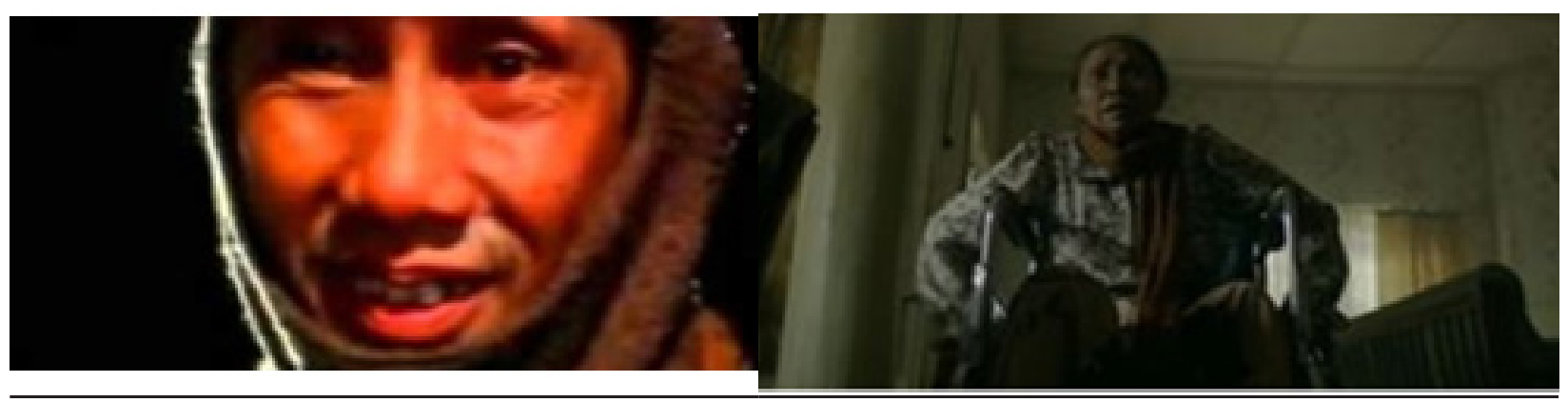

Pak Karto, penjaga kebun di film Pengabdi Setan 1980 diceritakan pak Karto sakit-sakitan karena asma.
Si nenek juga sakit-sakitan hanya bisa duduk di kursi roda. Memiliki kesamaan yaitu menjadi saksi kunci atas terrornya sebuah keluarga dari film Pengabdi Setan. 


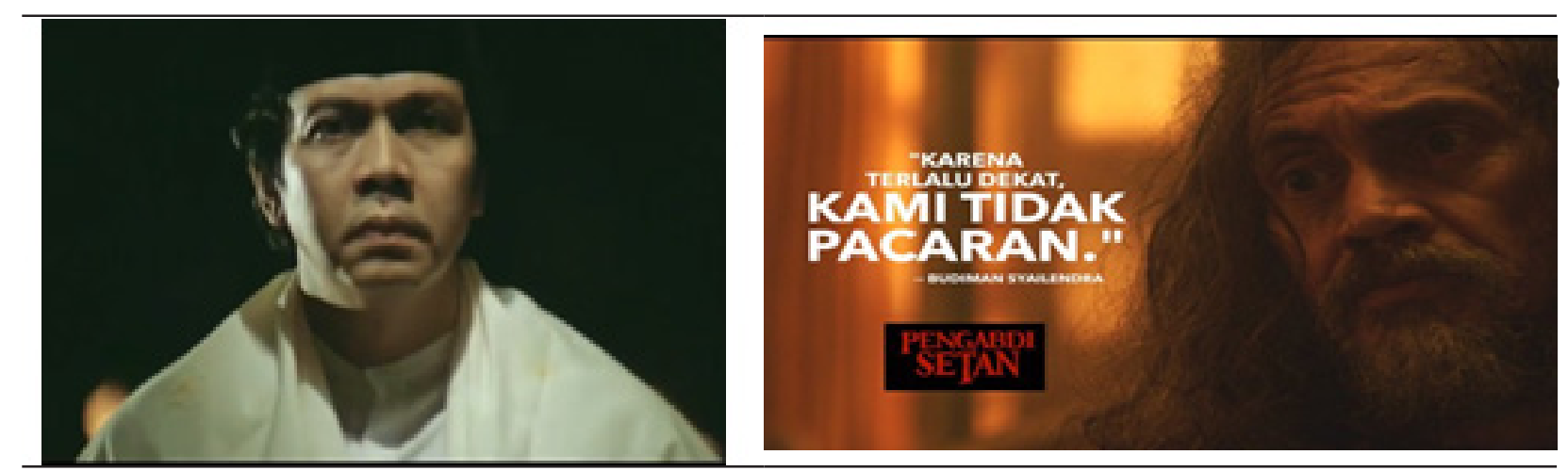

Sosok Ustaz di film Pengabdi Setan 1980

Banyak yang mengira bahwa sosok penyelamat menjadi tokoh yang penting karena dapat di Pengabdi Setan 2017 adalah seorang Ustaz namun mengalahkan teror setan dengan dibacakan ayat ternyata Budiman menjadi salah satu sosok nyata kursi. dengan menolong keluarga Rini saat di teror setan.

Budiman merupakan teman dari nenek.

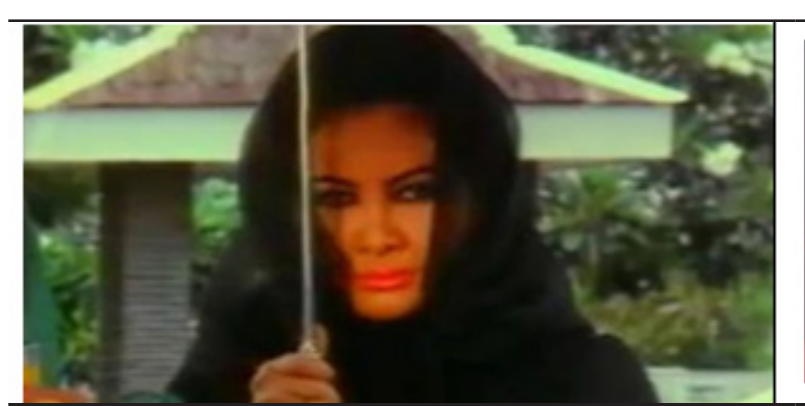

Pada film lama, teror keluarga diakibatkan

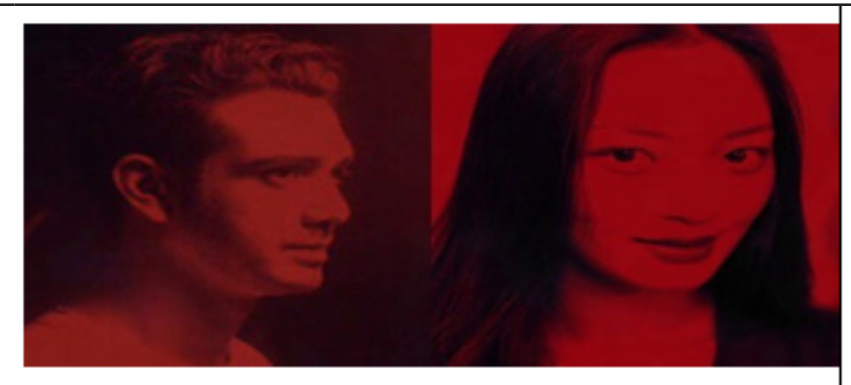

Darminah di film Pengabdi Setan 2017

oleh kelakukan iblis yang menyamar sebagai justru hanya ada di bagian akhir film, sosoknya pembantu keluarga, Darminah.

seperti misterius dan banyak membuat penasaran penonton hingga banyak yang memberikan asumsi.

Sumber: Hasil Pengolahan Data Penelitian, 2018

Berbeda dengan film Pengabdi Setan sebelumnya yang menampilkan suasana megah sehingga situasinya kontras dengan pesan horor yang disampaikan dalam film. Heider menyatakan bahwa film horor Indonesia mempunyai ciri khas yaitu, yaitu komedi, seks, dan religi (Debby et al., 2020). Penonton menyukai film horor Indonesia karena ketiga ciri tersebut. Selain kekuatan supernatural dan komedi dalam film horor Indonesia, terdapat juga 2 ciri khas lainnya yaitu penggunaan simbol agama dan tokoh agama sebagai protagonis (Debby et al., 2020a). Film Pengabdi Setan mengubah kekuatan supranatural dan religious sebagai bukan ciri utama, namun lebih mengkonstruksi ciri film horror yang seram dan banyak konflik sehingga penonton merasa tegang, histeris dan penuh teka-teki. Fenomena tersebut sebagai bentuk desakralisasi terhadap tokoh, ritual, maupun simbol agama yang memiliki unsur sakral atau nilai sakral (Debby et al., 2020). Perubahan tersebut tidak terlepas dari latar belakang, pengalaman dan karakteristik sutradara Joko Anwar yang mengedepankan 
otentitas 'rasa horor' dengan meneror ketakutan bagi penonton.

Film Pengabdi Setan 2017 kemasan isinya berbeda dengan film Pengabdi Setan 1980. Hal itu merupakan bentuk strukturisasi yang berlangsung karena era mempunyai struktur dan agensi sosial baru yang juga berbeda pola pikir dan latar belakang sosial budaya. Film Pengabdi Setan dalam proses produksi juga melakukan komodifikasi dengan mengubah isi film sebagaimana sudah dipaparkan dalam tabel sebelumnya sebagai supaya meselaraskan dengan struktur sosial saat ini. Penonton selaku agen atau individu telah mengkonstruksi mengenai sebuah film dengan membandingkan film Pengabdi Setan 1980 dan Pengabdi Setan 2017. PengabdiSetan 1980 menceritakan sebuah filmyang dilatarbelakangi dengan sebuahkonflik mengenai agama. Sedangkan Film Pengabdi Setan 2017 cenderung mengambarkan tokoh agama yang tidak mempunyai kekuatan yang dominan, yang dapat dikalahkan oleh Pengabdi Setan. Dominasi merupakan hasil dari dua jenis mobilisasi sumber daya, yaitu 1) sumber daya alokatif yaitu mengacu bentuk-bentuk kemampuan transformatif yang melahirkan perintah atas objek-objek, benda-benda atau fenomena material, 2) Sumber daya otoritatif yaitu merujuk pada jenis-jenis kemampuan transformatif yang melahirkan perintah atas orang-orang atau para aktor (Giddens, 2011).
Sumber otoritatif berlangsung karena alasan ekonomi yaitu target penonton. Tahun 1981 target penonton film Pengabdi Setan pada usia dewasa, namun tahun 2017 target penonton meluas pada remaja, atau anak milineal yang merupakan usia penonton terbanyak. Jika era sebelumnya, penonton film horor Indonesia menyukai film horor yang isinya dekat dengan dunia supranatural, dalam tahun 2017 khususnya film Pengabdi Setan, penonton Indonesia justru menyukai film horor yang cenderung rasional'. Cerita horror dalam film Pengabdi Setan telah dimodifikasi sesuai dengan masa produksi tahun 2017. Cerita menjadi unsur terpenting dalam produksi film dengan genre apapun (Haryanto, 2018). Dalam cerita mengandung produksi makna-makna dan pesan-pesan tertentu yang ingin dituturkan kepada penonton melalui praktik sinematografi atau gambar bergerak sebetulnya terletak dalam penataan sequence, bukan dalam shot atau scene, karena film pada hakikatnya adalah teks naratif yang 'menyampaikan cerita' (Budiman et al., 2013; Haryanto, 2018). Artinya telah terjadi perubahan sosial budaya penonton film horor Indonesia, walaupun belum sepenuhnya. Namun film horor dengan ciri baru telah diterima oleh masyarakat dan mereka menyukainya sehingga film Pengabdi Setan versi 2017 meraih penontoh terbanyak.

Film Pengabdi Setan dalam proses 
produksi juga melakukan komodifikasi dengan mengubah isi film sebagaimana sudah dipaparkan dalam tabel sebelumnya sebagai upaya meselaraskan dengan struktur sosial saat ini. Penonton selaku agen atau individu telah mengkonstruksi mengenai sebuah film dengan membandingkan film Pengabdi Setan 1980 dan Pengabdi Setan 2017. Pengabdi Setan 1980 menceritakan sebuah film yang dilatarbelakangi dengan sebuah konflik mengenai agama. Sedangkan Film Pengabdi Setan 2017 cenderung mengambarkan tokoh agama yang tidak mempunyai kekuatan yang dominan, yang dapat dikalahkan oleh Pengabdi Setan. Dominasi tergantung pada dua jenis mobilisasi sumber daya berbeda, yaitu sumber daya alokatif dan sumber daya otoritatif. Sumber daya alokatif mengacu pada kemampuankemampuan atau lebih tepatnya, pada bentukbentuk kemampuan transformatif yang melahirkan perintah atas objek-objek, bendabenda atau fenomena material. Sumber daya otoritatif merujuk pada jenis-jenis kemampuan transformatif yang melahirkan perintah atas orang-orang atau para aktor (Giddens, 2011).

Perubahan ideologi film sebagai bentuk pendobrakan dari realitas masyarakatyang sudah berubah dibandingkan 20 tahun sebelumnya, masyarakat saat ini sudah mempunyai alternatif pemikiran, sumber informasi yang beragam dan ketaatan kepada ulama sudah tidak seperti dalam film Pengabdi Setan pertama. Film mengandung pesan dari keinginan untuk merefleksikan kondisi masyarakat dan bahkan bersumber dari keinginan untuk memanipulasi penonton (McQuail, 2011). Berdasarkan pandangan tersebut, film tidak hanya menjadi alternatif hiburan semata, melainkan tersirat ideologi tertentu yang berimplikasi terhadap perubahan sikap, perilaku, dan pemikiran penonton. Konstruksi tokoh 'Ulama' direpresentasikan bukan kekuatan yang tidak dapat dikalahkan sebagaimana dalam gambaran film-film horor sebelumnya termasuk dalam film Pengabdi Setan yang diproduksi tahun 1980. Tanpa kita sadari, media yang kita anggap netral merupakan bagian dari persebaran kekuasaan strukturasi secara alokatif (Giddens, 2011).

Strukturasi pada film Pengabdi Setan merupakan hasil dari kekuasaan atau dominasi secara otoritatif agen-agen sosial budaya yang terlibat sebagai proses pembuatan film tersebut. Salah satu dominasi adalah sutradara yaitu Joko Anwar yang mengecap Pendidikan di Wheeling Park High School, West Virginia, USA, dan Institut Teknologi Bandung. Sutradara yang lahir pada tahun 1976 dapat dikategorikan sebagai individu yang melek teknologi dan media sosial dan digital, serta kritis, maka semua itu ikut menentukan proses strukturasi dan komodifikasi pembuatan film. Perbedaan pola pikir sebagai agen dan struktur sosial dengan 
sutradara film Pengabdi Setan yang pertama tahun 1981. Cerita horror dalam film Pengabdi Setan telah dimodifikasi sesuai dengan masa produksi tahun 2017.

Film Pengabdi Setan mengambil inspirasi dari peristiwa dan kecenderungan perubahan sosio-kultural masyarakat yang menyebabkan film laku keras. Artinya film sebagai media berhasil menyebarkan wacana ideologis yang dapat mengkonstruksi cara berpikir penonton mengenai 'gaya baru' terhadap ciri film horor. Struktur sosial dan agen berlangsung interplay sehingga membentuk system belief yang berbeda antara produser, sutradara, pemain dan para kru serta penonton film Pengabdi Setan 1980 dengan film Pengabdi Setan 2017 (Giddens, 2011). Perubahan juga terjadi dalam proses produksi terkait pemilik modal, film Pengabdi Setan pertama dibuat berasal dari Rapi Films dan yang kedua tetap diproduseri oleh Rapi Film generasi baru yaitu Gope T Samtani. Akan tetapi, kali ini Rapi Films berkolaborasi dengan CJ Entertainment yang merupakan perusahaan hiburan asal Korea Selatan sebagai distributor ke 42 negara (Priherdityo, 2018).

Kekuatan ekonomi menentukan superstruktur termasuk persoalan ideologi, agama, relasi sosial, politik maupun budaya. Artinya, produsen sebagai pemilik modal menentukan proses produksi, konten/isi film, promosi, marketing dan beragam unsur terkait lainnya. Hal ini yang dimaksudkan bahwa kelas pemodal dengan kemampuan modal dan alat produksinya mampu menggerakkan mekanisme dan modal produksi yang melibatkan kreator dan buruh dalam organisasi dan praktik kerja. Hal tersebut, menjelaskan bahwa kesadaran dalam proses produksi adalah kepentingan ekonomi melekat dalam proses produksi, distribusi dan konsumsi sebuah pesan media, termasuk film. Gagasan kesadaran adalah dasar bagi teori strukturasi. Ini adalah karakteristik utama dari agen manusia atau subjek yang strukturalisme telah menjadi sangat buta (Giddens, 2011).

Pemilik modal menentukan komodifikasi film dalam proses produksi, sebagai agen sosial yang tidak terpisahkan dari struktur sosial pembuat film di Indonesia. Semua agen struktur sosial merefleksikan diri secara dominan dalam proses konstruksi pembuatan sehingga film Pengabdi Setan. Faktanya strukturasi yang berlangsung tidak ada penolakan dari penonton terkait perubahan isi film, bahkan penonton membludak. Hal tersebut terbukti dengan jumlah penonton yang mencapai 4.2 juta orang (Samudro, 2019). Artinya film adalah media yang melakukan komifikasi pesan sesuai dengan struktur sosial dan interaksi agen-agen dalam proses strukturasi dapat interplay.

Hal ini menegaskan bahwa film bukan saja sebagai media hiburan dan persuasi, namun faktanya film mempunyai kekuatan menstranfer 
ideologi dan ekonomi politik dengan kekuatan bujukan atau persuasi yang sangat besar (Surahman, 2015). Dalam konteks ini telah berlangsung relasi antara media dan kekuatan ekonomi politik yang disebut Gedden sebagai proses strukturasi. Proses tersebut pasca reformasi, relasi integral antara media, politik dan ekonomi pasca semakin memperkuat institusi media massa dengan kekuatankekuatan politik dan ekonomi praktis-pragmatis (Alfani, 2014).

Kepentingan ekonomi politik mendominasi proses produksi, distribusi dan konsumsi media, seperti apa yang terjadi pada film Pengabdi Setan. Produksi film terkait erat dengan persoalan-persoalan sosial kultural yang melekat di masyarakat karena dapat memberikan keuntungan yang besar secara ekonomi maupun penyebaran ideologi (Karnanta, 2012; Smith, 2007). Sistem kapitalisme mendukung kepentingan produksi yang mampu menghasilkan kapital yang besar melalui sistem relasi kekuasaan dan hegemoni yang hanya menguntungkan pemilik modal. Sistem produksi melalui mekanisme industri budaya menjadi pendukung utama industri film sebagai industri budaya berkembang dengan pesat serta mempunyai nilai ekonomi yang sangat besar.

Strukturasi dipahami sebagai proses dimana struktur sosial melandasi aktivitas para agen. Dalam proses sosial yang diantarai oleh kekuatan ekonomi dan politik Gagasan tentang strukturasi ini pada awalnya dikembangkan oleh Anthony Giddens. Strukturasi merupakan menggambarkan tentang perubahan sosial sebagai proses yang mendeskripsikan bagaimana sebuah struktur diproduksi dan direproduksi oleh manusia yang berperan sebagai pelaku dalam struktur itu sendiri (Adila, 2011). Dalam proses produksi film Pengabdi Setan semuanya berlangsung dan mengarahkan semuan proses yang melibatkan semua agen sosial dengan nilai-nilai tertentu yang terlibat di dalamnya. Strukturasi berkaitan dengan relasi ide antar agen masyarakat, proses sosial dan praktik sosial dalam analisis struktur. Hasil akhir dari strukturasi adalah serangkaian hubungan sosial dan proses kekuasaan diorganisasikan di antara kelas (Alfani, 2014).

Relasi ekonomi politik mendominasi proses produksi, distribusi dan konsumsi film Pengabdi Setan 1980 dan 2017. Dominasi semakin menguat pada film Pengabdi Setan 2017, yang berupaya memperkuat posisi masyarakat atau penonton hanya sebagai objek media yang bernilai ekonomi. Berbagai perubahan dilakukan untuk masuk ke dalam alam bawah sadar penonton sehingga menerima perubahan bahkan menjadi referensi untuk memahami simbol-simbol mistik gaya baru. Cerita tentang supranarural dan mistis tidak perlu harus dikemas 
dengan gaya lama, meliankan dapat dikemas dengan gaya kekinian, didukung oleh pemainpemain yang menarik dan muda, sehingga tidak menakutkan walaupun tetap sebagai film mistis. Perubahhan juga dilakukan pada peran ustad, yang mana dalam Film Pengabdi Setan 1980 merupakan sentral dalam menyelesaikan masalah mistis karena mempunyai kekuatan spiritual, kemasannya berbeda dalam film Pengabdi Setan 2017, ustad bukan lagi satusatunya kekuatan dalam menyelesai mistis, dan bisa kalah oleh kekuatan mistis. Hal tersebut relevan dengan pergesehan pengaruh ustand yang peran sentralnya sudah bergeser dengan kekuatan-kekuatan 'magis' lainnya seperti sosial media dan berbagai aktivitas ekonomi lainnya.

Pergulatan hebat berlangsung dalam setiap proses produksi, distribusi dan konsumsi media, termasuk film. antara kepentingan ekonomi dan politik berdasarkan ideologi dalam proses produksi konten media. Film Pengabdi Setan mengusung Ideologi kapitalis yang mengedepankan kepentingan ekonomi walaupun mengaburkan nilai-nilai keyakinan masyarakat mengenai kekuatan mistis. Hal tersebut merupakan realitas baru yang terjadi di tegah masyarakat walaupun secara vulgar tidak dinyatakan. Proses tersebut merupakan sebuah gambaran sejauh mana media mengambil posisi di tengah pergulatan kepentingan dan ideologi dalam setting kepemilikan (ekonomi) dan setting kekuasaan (politik) (Alfani, 2014).

Dalam proses produksi tidak dapat dibantah bahwa relasi sosial, ekonomi dan jalinan kekuasaan yang berlangsung dalam produksi dan distribusi media. Kepentingan ekonomi menjadi ideologi yang mendominasi proses produksi film Pengabdi Setan. Kondisi tersebut sebagaimana konsep Peter Golding dan Graham Murdock dalam James Currant \& Michael Gurevitch, yaitu perspektif ekonomi politik media ke dalam dua perspektif besar, yaitu perspektif liberal dan perspektif kritis (Adila, 2011). Perspektif liberal cenderung memfokuskan pada isu pertukaran pasar dimana konsumen akan secara bebas memilih komoditas media. Sedangkan pandangan Marxis, preferensi pemilik modal memungkinkan institusi media mengambil peran sebagai penyebar kesadaran palsu yang melemahkan kesadaran khalayak. Media dapat digunakan untuk melancarkan hegemoni dengan menutupi atau merepresentasikan kepentingan kelas berkuasa (Adila, 2011; Karnanta, 2012). Film Pengabdi Setan telah berhasil mengubah berhasil melakukan hegemoni yang dilakukan agen-agen sosial terutama pemilik modal utnuk emnciptakan kesadaran palsu terkait ideologi yang terkandung dalamfilmtersebut. Disamping, film ini pada tataran industryikapitalisme media juga sangat berhasil.

Hegemoni kekuasan ekonomi dan politik 
dalam struktur budaya produksi film melekat dan integral dalam strukturasi yang berlangsung. Tidak ada struktur dan agen yang ahistoris, namun semua mengalami strukturasi. Relasi antara kekuatan ideologi, ekonomi dan politik dalam proses produksi konten media, seperti film berdsarkan tiga ciri pemikiran Ekonomi Politik Mosco yakni (1) pendekatan ekonomi politik adalah bagian dari studi perubahan sosial dan transformasi budaya; (2) pendekatan ekonomi politik tertarik menjelaskan hubungan sosial secara menyeluruh dalam bidang ekonomi, politik, sosial, maupun budaya; (3) pendekatan ekonomi politik memasukkan prinsip-prinsip filosofi serta mempunyai ketertarikan terhadap nilai-nilai dan prinsip-prinsip moral (Karnanta, 2012).

Pendekatan Ekonomi Politik tidak terlepas dengan wacana mengenai globalisasi yang dipahami mengusung agenda kapitalisme global berikut implikasinya terhadap kehidupan sosiokultural yakni bentuk-bentuk imperialisme budaya seperti terurai dalam dua bagian di atas. Proses ekonomi politik dalam sebuah produksi film Pengabdi Setan melibatkan pihak asing dalam pendanaan, teknologi produksi, dan distribusi di Indonesia dan manca negara. Artinya di balik jargon development of undevelopment dan dana hibah dari lembaga donor asing, telah terjadi suatu mekanisme pasar yang melingkar di mana Indonesia sekadar menjadi konsumen (Karnanta, 2012). Media massa secara utuh dilihat sebagai produk kebudayaan yang harus diberikan kesempatan sebebas-bebasnya serta seluas-luasnya untuk berkompetisi di dalam pasar sebagai bentuk ekonomi politik liberal yang lebih menekankan pada proses dan dampak dari liberalisasi pasar (Karnanta, 2012).

Di sisi lain, varian ekonomi politik kritis memberikan affirmasi pada pengorganisasian kepemilikan dan produksi industri budaya. Golding dan Murdock menempatkan ekonomi politik media pada pendekatan kritis yang menekankan pada beberapa isu sentral yaitu holistik dan historis (Triyono, 2012). Holistik bahwa seluruh produksi mempunyai interelasi antara dinamika sosial, politik dan budaya dalam suatu masyarakat. Artinya media dalam totalitas sistem yang lebih luas sebagai bagian integral dari proses-proses ekonomi, sosial dan politik yang berlangsung di masyarakat. Historis menjelaskan bahwa perubahanperubahan dan dialektika yang terjadi berkaitan dengan posisi dan peranan media komunikasi sistem kapitalisme global. Praksis bahwa segisegi aktivitas manusia bersifat kreatif dan bebas dalam rangka untuk mengubah keadaan, terutama ditengah arus perubahan sosial dan kapitalisme (Triyono, 2012). Produksi sebuah media termasuk film akan mengalami perubahan terus menerus seiring dengan perubahan 
struktur dan agen yangb memproduksi film, serta masyarakat yang menjadi objek persuasi film yang diproduksi.

Proses tersebut memperkuat ideologi yang diusung oleh film sebagai media. Ideologi dapat dipahami sebagai suatu sistem tentang penjelasan akan eksistensi suatu kelompok sosial, dan atau individu, di mana sejarahnya memproyeksikan ke masa depan tentang adanya rasionalisasikan hubungan kekuasaan antar kelompok atau kelas-kelas sosial di dalamnya. Ideologi adalam suatu perangkat koheren ide dan nilai yang mengungkapkan pandangan tentang dunia sosial, ekonomi, dan politik, yang mempertanyakan bagaimana keadaan dunia sekarang dan bagaimana dunia itu seharusnya (Toni, 2017). Makna-makna yang mungkin didapatkan dari analisis tentang teks-teks media cenderung ideologis. Artinya Konsep ideologi yang dibangun sekaligus mitos dalam proses komunikasi atau produksi sebuah konten media termausuk film Pengabdi Setan.

Proses doktrinisasi ideologi dalam produsksi sebuah film berlangsung integral dalam stuktur dan agen-agen yang terlibat dalam proses produksi. Ideologi juga melekat dalam distribusi dan konsumsi media. Film distribusi film Pengabdi Setan dikendalikan oleh kekuatan ekonomi dan kekuasan tertentu (politik), serta proses konsumsi, dimana penonton menjadi objek ekonomi kapitalisme yang menerima persuasi sehingga memunculkan kesadaran palsu tergadao perubahan-perubahan nilai yang berlasung dalam film dan kemudian mengekalkan pemahaman masyarakat atas perubahan nilai. Telah berlangsung ketidaksetaraan sosial politik dan ekonomi, namun masyarakat menerima sebagai suatu kewajaran atau alamiah, bukan sebuah persoalan yang harus dikritisi. Penonton cenderung tidak mempunyai kekuatan untuk menolak kekuatan ideologi, dan ekonomi politik karena mereka terkooptasi oleh lingkaran kekuatan tersebut. Dalam konteks ini, ideologi beroperasi sebagai sarana kontrol sosial yang diungkapkan melalui melalui bentuk hiburan seperti film. Individu menjadi media penghantar nilai-nilai ideologi yang justru memperkuat sistem belief sehingga perubahan diterima sebagai kekuatan dan kebenaran baru yang semestinya. Individu masih berupa objek kapitalime industri media yang terperangkap dalam kekuatan ideologi yang diantarai kekuatan ekonomi pemilik media dan kekuasan politik.

\section{SIMPULAN}

Berdasarkan data dan analisis, maka dapat diambil simpulan bahwa dalam proses produksi film Pengabdi Setan telah mengalami strukturasi dan konstruksi sosial. Struktur dan agent integral dalam proses produksi sehingga kekuatan ideologi semakin subur dna kuat 
karena disukung oleh kepentingan ekonomi dan kekuasaan (politik). Dalam pertimbangan ekonomi, Film Pengabdi Setan menjadi film nomor satu pada tahun 2017 dan produser yang dikatakan sebagai pihak pemilik modal mendapatkan profit yang sebesar-besarnya. Disisi lain, kekuasaan politk teleh mampu menempatkan film sebagai media komunikasi dibawah kendali pihak-pihak yang menetukan proses produksi.

Proses produksi film Pengabdi Setan melalui tiga tahap produksi yaitu pra-produksi, produksi dan pasca-produksi. Semua proses produksi dipersiapkan sematang mungkin agar produksi film dapat berjalan lancar, dan dalam proses tersebut melampau struktur sosial dan melibatkan agent-agen. Dalam proses produksi proses pembuatan film Pengabdi Setan 2017 ini terdapat 3 gugus besar dalam teori strukturasi Anthony Giddens yaitu strukturasi yang merupakan semua tindakan sosial yang melibatkan struktur dan agenagen dalam kehidupan sosial budaya, ekonomi dan politik. Struktur dan agen-agen inilah yang menentukan nilai-nilai dalam proses produksi. Ideologi kapitalisme mendominasi proses produksi sehingga pertimbangan utama adalah memperoleh keuntungan dari produksi film yang dilakukan. Dalam proses tersebut, masyarakat dan nilai-nilai kemudian menjadi objek produksi yang harus diubah secara sadar agar mencuipkan pemahaman baru. Sekaligus menyesuaikan dangan struktur dan agen-agen baru.

Proses interaksi manusia sebagai agen melibatkan tindakan sosial yang erat dalam aktivitas atau praktik yang terus menerus dijalankan manusia. Artinya tidak ada struktur sosial yang tidak memperngaruhi agen-agen sosial. Perdebatan tersebut menjelaskan bahwa 1) Struktur Penandaan (skema simbolik, pemaknaan,penyebutan,danwacana),2)Struktur penguasaan atau dominasi penguasa (politik) dan barang/hal (ekonomi), bahwa industri film didominasi oleh kelompok masyarakat yang orang India, terbukti dari produser Rapi Films (pemilik modal) atas film Pengabdi Setan ini berasal dari India namun murni untuk berbisnis.

3) Strukturasi mempengaruhi proses produksi film Pengabdi Setan yang melibatkan agenagen sosial yang terikat dengan niali -nilai sosial budaya, ekonomi dan politik. 4) Telah terjadi doktrinisasi ideologi dalam proses produksi film sebagai media massa yang dipercaya tidak mungkin terlepas dari kekuatan ideologi. Ideologi dalam proses produksi adalah adanya penetrasi terhadap nilai-nilai baru dalam film yang mengubah kesadaran khalayak. Namun perubahan tersebut tetap memposisikan mereka sebagai bagian hari kekuatan hegemoni pemilih modal yang cenderung menempatkan khalayak 'hanya' sebagai mesin uang dalam sebuah 
indstri media. Namun disisi lain telah terjadi perubahan sosial budaya terkait isi film yang menampilkan karakteristik horror yang berbeda dibandingkan film 'Pengabdi Stan 1980. Film Pengabdi Setan dan berbagai film dengan genre horor merupakan sebuah komoditas yang dapat dimanfaatkan secara baik dalam jaring globalisasi untuk mengembangkan dan melibatkan para rumah produksi, film maker di mata dunia. Artinya kekuatan ekonomi mengatur kekuasaan politik agar sesuai dengan proses strukturasi yang berlangsung.

\section{DAFTAR PUSTAKA}

Adila, I. (2011). SPASIALISASI DALAM EKONOMI POLITIK KOMUNIKASI ( Studi Kasus MRA Media ). Jurnal Ilmu Komunikasi, 1(1).

Alfani, H. (2014). Perspektif Kritis Ekonomi Politik Media (Konglomerasi, Regulasi dan Ideologi). Avant Garde, Jurnal Ilmu Komunikasi, 2(2), 10-26.

Bekraf. (2019). Pemandangan Umum Industri Film Indonesia. BEKRAF (Badan Ekonomi Kreatif).

Budiman, C., Abdullah, I., \& Simatupang, G. R. L. (2013). Retorik dan Makna Ideologis Karya Instalasi dalam Film Opera Jawa Garin Nugroho. 14(1), 1-8.

Cheng, T. (2014). Public Relations and Promotion in Film: How It 's Done and Why It 's Important.

Craig, G. (2004). The media, politics, public life, Allen \& Unwin. Crows Nest NSW.

Creswell, W. J. (2013). Research Design Pendekatan Kualitatif, Kuantitatif, dan
Mixed. Pustaka Pelajar.

Databoks.com. (2017). Pengabdi Setan Film Terlaris 2017.

Debby, Y., Hartiana, T. I. P., \& Krisdinanto, N. (2020). Desakralisasi film horor Indonesia dalam kajian reception analysis. ProTVF, 4(1), 1. https://doi.org/10.24198/ptvf. v4i1.24171

Dwita, D. (2016). Jurnal ipteks terapan. 4, $252-261$.

Fathurizki,A., \& Mei, R. (2018). PORNOGRAFI DALAM FILM : ANALISIS RESEPSI FILM “MEN , WOMEN \& CHILDREN ” Film Men, Women FILM “ MEN, WOMEN \& CHILDREN " tidak masuk ke Indonesia - Penonton di Indonesia hanya bisa menikmati film ini dengan menonton secara online di website streaming fil. 2(44).

Giddens, A. (2011). The Constitution of Society. Pedati.

Haryanto, D. (2018). BIOPIC FILM AND POLITICAL IDENTITY : CONTESTATION OF DIVERSITY OF IDEOLOGY IN INDONESIAN MOVIES TEXT POST-SOEHARTO REGIME. Jurnal Seni Media Rekam, 10(1). https:// doi.org/10.33153/capture.v10i1.2196

Heryanto, G. G. (2017). Ekonomi Politik Media Penyiaran: Rivalitas Idealisme Nilai Islami dan Mekanisme Pasar. Communicatus: Jurnal Ilmu Komunikasi, 1(1), 85-98. https://doi.org/10.15575/cjik.v1i1.1212

Inayah, S. S. (2015). ASPEK EKONOMI, POLITIK, DAN KULTURAL MEDIA MASSA. Lentera, IX(2), 119-127.

Incekara, A., Sener, S., \& Hobikoglu, E. H. (2013). Economic evaluation of the film industry in terms of strategic management within the scope of the creative innovative industries: The case of Turkey. 99, 636-647. https://doi.org/10.1016/j. 
sbspro.2013.10.534

Javandalasta, P. (2011). 5 hari mahir bikin film. Mumtaz Media.

Karnanta, K. Y. (2012). Ekonomi Politik Film Dokumenter Indonesia. 1(1), 1-11.

Khoiri, A. (2018). Penampakan "Pengabdi Setan" di 42 Negara. CNN Indonesia.

Kristeva, N. S. S. (2015). Sejarah Ideologi Dunia. Lentera Kreasindo.

Lamsal, M. (2012). The Structuration Approach of Anthony Giddens. Himalayan Journal of Sociology and Anthropology, 5, 133. https://doi.org/10.3126/hjsa.v5i0.7043

Matos, C. (2017). Mass media and globalization. August.

Mayopu, R. G. (2017). Sebuah Analisis Framing terhadap Pemberitaan Program Berita Investigasi Televisi. 107-126.

McQuail, D. (2011). Teori Komunikasi Massa McQuail Edisi Buku Denis McQuail (2nd ed.). Salemba Humanika.

McQuail, D. (2012). Teori Komunikasi Masa Mcquail Buku 1 (1st ed.). Salemba Humanika.

MD Pictures Tbk. (2019). Diclamer.

Nickel, J. (2010). Horror and the Idea of Everyday Life: On Skeptical Threats in Psycho and The Birds (Fahy T (ed.)). The University Press of Kentucky.

Nugraeni, E. K. (2014). MITOS TEMBANG DURMA KUNTILANAK DALAM FILM HOROR KUNTILANAK.

Nugroho, C. (2018). RELASI KUASA MEDIA DAN ISU GENDER POWER RELATION AND GENDER ISSUE Media saat ini bukan lagi sebagai media penyampai pesan ( mediasi) tetapi telah menjadi media yang mempengaruhi opini dan sikap masyarakat ( mediatisasi ). Hal ini lah dimana media yang se. 2(1).

Nwokedi, \& Ekpereamaka, M. (2018). Film as a Mass Medium : Audience Perception of Home Video Films as Representation of Realities in Nigeria ( Study of Residents in Awka South ). 89256.

Oktavianus, H. (2015). Praktek Eksorsis Di Dalam Film Conjuring. E-Komunikasi, $3(2), 3$.

Permana, R. S. M., Puspitasari, L., \& Indriani, S. S. (2018). Strategi Promosi Pada Tahapan Pra-Produksi Film 'Haji Asrama' (Has). ProTVF, 2(2), 145. https://doi. org/10.24198/ptvf.v2i2.20818

Priherdityo, E. (2018). Kuasai Hong Kong, “Pengabdi Setan” Siap ke New York. CNN Indonesia.

Samudro. (2019). Daftar 10 Film Horor Indonesia dengan Jumlah Penonton Terbanyak - Tirto. Tirto.Id.

Shoemaker, P. J., \& Reese, S. D. (1996). Mediating The Message, Theories of Influences on Mass Media Content,NY. Longman.

Smith, A. (2007). The Wealth of Nation.

Subandi, Z. E., \& Sadono, T. P. (2018). KOMODIFIKASI , SPASIALISASI , DAN STRUKTURASI DALAM MEDIA BARU DI INDONESIA ( Ekonomi Politik Komunikasi Vincent Mosco Pada Line Webtoon ). National COnference of Creative Industry, September, 5-6.

Sunnerbrink, T. and R., \& Lisa. (2016). and/ as Ethics. Projet Muse. University of Wisconsin Press., 45(3), 3-15. https://doi. org/10.3368/ss.45.3.3.

Surahman, S. (2015). Representasi Feminisme Dalam Film Indonesia, Analisis Semiotika Terkait Feminisme Pada Film 7 Hati 7 Cinta 7 Wanita). JURNAL LISKI, 1(2).

Sutorini, M. P., Alif, M., \& Sarwani. (2019). Semiotika Gender dalam Film Brave. 3(1), 101-112. 
Tawaang, F., \& Imran, H. A. (2017). ( Studi Ideologi Media Pemilik Akun Medsos ) ( The Media Ideology Study of Social Media Account Owner ). Jurnal Studi Komunikasi Dam Media, 21(1), 59-68.

Toni, A. (2016). Ideologi Film Garin Nugroho Kajian Semiotika Pada Film Daun Diatas Bantal. Communication, 7(2), 1-25.

Toni, A. (2017). Ideologi Film Garin Nugroho. Pantun Jurnal Ilmiah Seni Budaya, 2(1), 11-30.

Triyono, A. (2012). Produksi teks dalam perspektif ekonomi politik media. KomuniTi, I(1), 18-29.

Vera, N. (2014). Komunikasi Massa. Ghalia Indonesia.

Vivanews.com. (2018). Bangga, Pengabdi Setan Kembali Diganjar Penghargaan Global. Vivanews, Com.

Wasitaatmadja, F. F. (2019). Pemikiran Islam
Dalam Pembentukan Nasionalisme Indonesia: Sebuah Analisis Sejarah Hukum.

Whittington, R. (2015). Giddens, structuration theory and strategy as practice. December. $\quad$ https://doi.org/10.1017/ CCO9781139681032.009

Wibowo, T. O. (2018). Fenomena Website Streaming Film di Era Media Baru: Godaan, Perselisihan, dan Kritik The Phenomena of Movie Streaming Websites in New Media Era: Temptation, Disputes , and Critique. 6(2), 191-203.

Wijiharjono, N. (2017). KAJIAN PERKEMBANGAN PENELITIAN PEMASARAN FILM. AGREGAT, Jurnal Ekonomi Dan Bisnis, 1(2), 247-271. https://doi.org/10.22236/agregat Yin, R. K. (2013). Studi Kasus Desain dan Metode. Raja Grafindo Persada. 